\title{
Status of Agents Targeting the HGF/c-Met Axis in Lung Cancer
}

\author{
Oshin Miranda ${ }^{1}$, Mariya Farooqui ${ }^{1}$ and Jill M. Siegfried ${ }^{1,2, *}$ \\ 1 Department of Pharmacology and Masonic Cancer Center, University of Minnesota, \\ Minneapolis, MN 55455, USA; miran129@umn.edu (O.M.); faroo001@umn.edu (M.F.) \\ 2 Department of Pharmacology, University of Minnesota, 321 Church Street SE, 6-120 Jackson Hall, \\ Minneapolis, MN 55455, USA \\ * Correspondence: jsiegfri@umn.edu; Tel.: +1-612-235-2321
}

Received: 28 June 2018; Accepted: 13 August 2018; Published: 21 August 2018

\begin{abstract}
Hepatocyte growth factor (HGF) is the ligand for the tyrosine kinase receptor c-Met (Mesenchymal Epithelial Transition Factor also known as Hepatocyte Growth Factor Receptor, HGFR), a receptor with expression throughout epithelial and endothelial cell types. Activation of c-Met enhances cell proliferation, invasion, survival, angiogenesis, and motility. The c-Met pathway also stimulates tissue repair in normal cells. A body of past research shows that increased levels of HGF and/or overexpression of c-Met are associated with poor prognosis in several solid tumors, including lung cancer, as well as cancers of the head and neck, gastro-intestinal tract, breast, ovary and cervix. The HGF/c-Met signaling network is complex; both ligand-dependent and ligand-independent signaling occur. This article will provide an update on signaling through the HGF/c-Met axis, the mechanism of action of HGF/c-Met inhibitors, the lung cancer patient populations most likely to benefit, and possible mechanisms of resistance to these inhibitors. Although c-Met as a target in non-small cell lung cancer (NSCLC) showed promise based on preclinical data, clinical responses in NSCLC patients have been disappointing in the absence of MET mutation or MET gene amplification. New therapeutics that selectively target c-Met or HGF, or that target c-Met and a wider spectrum of interacting tyrosine kinases, will be discussed.
\end{abstract}

Keywords: hepatocyte growth factor (HGF); c-Met (mesenchymal epithelial transition factor or hepatocyte growth factor receptor); targeted therapy; lung cancer

\section{Biology of c-Met and Its Ligand, HGF 24pt}

The c-Met oncogene was first isolated from a human osteosarcoma cell line, which contained a DNA rearrangement: the translocated promoter region (TPR) locus on chromosome 1 was fused to the $M E T$ gene on chromosome 7 [1]. The MET gene produces a protein that is a tyrosine kinase receptor. The c-Met receptor, whose only known ligand is hepatocyte growth factor (HGF) [2], exists as a disulfide-linked heterodimer of the $\alpha$ and $\beta$ chains, which forms upon proteolytic cleavage of the c-Met precursor [1]. The protein contains an extracellular domain for ligand binding, a membrane spanning domain, a juxtamembrane portion, the catalytic kinase domain, and a C-terminal docking site [3]. In the tumor microenvironment, growth factors and cytokines are frequently secreted that are capable of activating or further enhancing metastasis by developing motility and invasiveness to the tumor cells. Hepatocyte growth factor (HGF), the ligand for c-Met, was identified as a secreted factor responsible for enhancement of motility and invasion, that also caused cell scattering [2]. HGF in the tumor microenvironment can be derived from either the tumor cells or the tumor-associated stromal cells [2], and in lung cancer is mainly produced by the mesenchymal cells in the stroma. 
HGF is primarily a paracrine factor produced by mesenchymal cells and fibroblasts. Under special circumstances, such as hypoxia, cancer epithelial cells can secrete HGF [3].

HGF, such as the c-Met receptor, is produced in an inactive state and then converted into its active form via proteolysis. The active state of HGF consists of four Kringle domains (K1-K4), an amino (N) domain and a serine protease homology domain (SPH), whose interactions facilitate receptor dimerization [4]. The binding of active HGF to c-Met leads to oligomerization of receptor, activation of the catalytic portion, tyrosine residue autophosphorylation, and docking of substrates, causing activation of downstream signaling processes $[5,6]$.

Binding of HGF to c-Met leads to autophosphorylation on the tyrosine residues Y1234 and Y1235 at the tyrosine kinase domain, activating further autophosphorylation of Y1349 and Y1356 residues near the $\mathrm{COOH}$ terminus. This activates the phosphotyrosine multifunctional docking site, which recruits intracellular adapters through Src and activates downstream signaling events [7]. Another important effect of HGF-mediated activation of c-Met is the stimulation of downstream effectors through the RAS/mitogen-activated protein kinase (MAPK) signaling pathway [8]. The HGF/c-Met pathway is also modulated by other proteins such as integrins which work as a platform that promotes the activation of RAS and PI3K, plexin B1, semaphorin and the death receptor Fas [9]. A number of biological activities such as cell proliferation, cell survival, motility function and morphogenesis are triggered by c-Met downstream signaling through these second messengers $[6,7]$.

It is also well-established that activation of other tyrosine kinases participate in maximizing HGF/c-Met effects. The epidermal growth factor receptor (EGFR) plays a paramount role in potentiating c-Met-mediated cell proliferation, cell invasion and cell survival [10]. EGFR activation can cause a Src-dependent activation of c-Met that is ligand independent [11]. Likewise, downstream of c-Met activation, $\mathrm{PGE}_{2}$ release occurring after COX2 induction can increase activity of matrix metalloproteinases that release EGFR ligands such as amphiregulin [12]. EGFR and c-Met can have a synergistic effect to advance the malignant phenotype $[13,14]$. Other oncogenic mechanisms work to enhance c-Met action. For example, c-Met along with insulin-like growth factor 1 receptor can synergistically increase cell invasion and cell migration in cancer cells [15]. RAS protein in its activated form induces c-Met expression through a positive feedback mechanism [16]. Hypoxia is also known to positively regulate c-Met activity via tumor angiogenesis [17]. A complex system of reinforcing interactions modulate and govern the magnitude and duration of c-Met signaling in the cell.

\section{HGF/c-MET Axis in Non-Small Cell Lung Cancer}

Generally, activation of c-Met by HGF is controlled through release of ligand by a paracrine process in which mesenchymal cells and cells of the innate immune system secrete HGF, followed by ligand activation on the cell surface and internalization of the activated receptor. In embryonic development, the HGF/c-Met system is active as organs are forming, but is largely silent in the adult, unless triggered during wound healing. In a variety of cancers however, the HGF/c-Met pathway is constitutively activated. The mechanism of activation include gene amplification, over-expression of the c-Met and/or HGF proteins, increased cross-signaling between c-Met and other tyrosine kinases, and MET gene mutation. Amplification of the MET gene has been found in a number of solid tumor types, including gastric cancer, where sensitivity to a c-Met tyrosine kinase inhibitor was high, and the c-Met pathway was important in maintaining cell survival [18]. Cancer cells containing MET gene amplification were highly dependent on c-Met signaling for both proliferation and cell survival.

c-Met overexpression often occurs in the absence of gene amplification. In breast cancer, c-Met overexpression was an independent predictor of aggressive malignancy with poor patient survival [19]. Overexpression of c-Met protein is also commonly found in NSCLC tissues [20]; several comparative studies detected c-Met overexpression in $60 \%$ of cases, while phospho- c-Met was elevated in $40-100 \%$ cases [21,22]. Increased protein expression, as compared to the level measured in normal tissues, has been observed in multiple neoplasms, and the degree of protein overexpression is often 
related to stage and extent of tumor progression [21,22]. c-Met overexpression was associated with advanced stage of disease, poor outcome and poor survival rates in lung and breast cancer [23-25].

A rare mechanism that leads to c-Met activation is activating mutations. Both missense germ line mutations in the tyrosine kinase domain and rare sporadic mutations have been detected in less than $1 \%$ of renal carcinoma, melanoma, small-cell lung carcinoma and mesothelioma [26]. Oncogenic mutations are found outside the kinase domain, such as mutations in the semaphorin domain (E168D, L229F, S323G, and N375S) and the juxtamembrane domain (R988C, T1010I, S1058P, and exon 14 deletions) of NSCLC cells [26]. The phosphorylation of Y1003, located in the juxtamembrane domain, is responsible for internalization of the c-Met receptor by association with the CBL (Casitas B-lineage Lymphoma) ubiquitin ligase. When there is a deletion of exon 14, the loss of Y1003 leads to c-Met accumulation on the cell surface and high HGF stimulation contributes to cancer progression [26]. Although semaphorin domain and juxtamembrane domain c-Met mutations develop at a low frequency (about $4 \%$ of NSCLCs) they provide proof of the oncogenic capacity of this axis.

\section{HGT/c-Met Axis in Small Cell Lung Cancer (SCLC)}

Accumulating evidence shows that activation of the HGF/c-Met pathway in SCLC cells also leads to increased tumor growth and survival. Many small cell tumors have increased plasma levels of HGF and SCLC can also contain MET amplification. In an in vivo model, c-Met inhibitors such as crizotinib and golvatinib arrested the cell cycle and led to decreased SCLC cell growth and metastasis. This indicates that some SCLC may be sensitive to inhibition of the c-Met pathway. MET amplification was also shown to promote resistance towards anti-cancer drugs in SCLC [27]. In an orthotopic model, c-Met inhibitors arrested metastasis in SCLC cells with elevated HGF levels [28]. A recent report found activation of the c-Met pathway in chemoresistant or chemorelapsed SCLC cell lines, which occurred through increased HGF levels and increased MET gene amplification. Inhibition of c-Met caused anti-tumor effects on these chemoresistant SCLC cell lines both in vitro and in vivo. Thus HGF/c-MET-mediated signaling may be important in growth and progression of SCLC [29].

\section{Therapeutics to Inhibit the HGF/c-Met Axis}

The HGF/c-Met axis has been targeted in several ways for potential cancer treatment, including targeting receptor activation and ligand binding. Multiple agents (small molecule tyrosine kinase inhibitors [TKIs] of c-Met and antibodies directed against either the c-Met protein or HGF) have completed or are currently in clinical trials. Active clinical trials targeting this pathway, including new investigational agents, are summarized in Table 1. Despite the common finding that the HGF/c-Met axis is overactive in many NSCLC, results of most completed clinical trials in patients without genetic alterations in the MET gene were disappointing, with few objective responses, even in combination therapy trials. Patients with amplification or mutation of the MET gene showed high response rates to HGF or c-Met targeting, suggesting these genetic changes are associated with c-Met pathway addiction, which is needed for clinical response to agents tested to date. Results of completed trials and ongoing clinical testing of the agents in Table 1 will be discussed by the mechanism of action below. 
Table 1. Active or Recent Clinical Trials of hepatocyte growth factor (HGF)-MET Inhibitors in Lung Cancer or in Solid Tumors.

\begin{tabular}{|c|c|c|c|c|c|}
\hline Agent(s) and Mechanism & Trial Phase & Endpoints & $\begin{array}{c}\text { Patient } \\
\text { Population/Indication }\end{array}$ & Study Design & $\begin{array}{l}\text { Clinical Trial Identifier and Status } \\
\text { Source: } \text { www.Clinicaltrials.gov }\end{array}$ \\
\hline $\begin{array}{l}\text { Capmatinib (INCB28060)c-Met } \\
\text { ATP-competitive inhibitor }\end{array}$ & 1 & Safety, tolerability, PK & $\begin{array}{l}\text { c-MET-dysregulated } \\
\text { advanced solid tumors }\end{array}$ & $\begin{array}{l}\text { Open Label, Dose Escalation } \\
\text { Study of Tablet Formulation }\end{array}$ & $\begin{array}{c}\text { NCT02925104 } \\
\text { Status: Recruiting }\end{array}$ \\
\hline Capmatinib & 1 & Safety & $\begin{array}{l}\text { Malignant NSCLC with } \\
\text { MET exon } 14 \text { skipping } \\
\text { alteration }\end{array}$ & $\begin{array}{c}\text { Capmatinib oral daily } \\
\left(50-740 \mathrm{mg} / \mathrm{m}^{2}\right) \text { 21-day cycles }\end{array}$ & $\begin{array}{c}\text { NCT02750215 } \\
\text { Status: Active, not recruiting }\end{array}$ \\
\hline $\begin{array}{l}\text { Cabozantinib (XL184) } \\
\text { c-Met, VEGFR2, and RET } \\
\text { ATP-competitive inhibitor }\end{array}$ & 2 & Efficacy & $\begin{array}{l}\text { Advanced or metastatic } \\
\text { solid tumors }\end{array}$ & $\begin{array}{c}\text { All subjects start cabozantinib } \\
\text { at } 40 \mathrm{mg} \text {. Those who tolerate } 40 \\
\mathrm{mg} \text { for } 2 \text { cycles will escalate to } \\
60 \mathrm{mg}\end{array}$ & $\begin{array}{c}\text { NCT02101736 } \\
\text { Status: Active, not recruiting }\end{array}$ \\
\hline Cabozantinib (XL184) & 2 & Safety/efficacy & $\begin{array}{l}\text { Advanced NSCLC, RET, } \\
\text { ROS1, or NTRK } \\
\text { fusion-positive }\end{array}$ & $\begin{array}{l}\text { Initial dose of } 60 \mathrm{mg} \text { orally } \\
\text { daily for } 28 \text {-day cycles }\end{array}$ & $\begin{array}{l}\text { NCT01639508 } \\
\text { Status: Recruiting }\end{array}$ \\
\hline $\begin{array}{c}\text { BMS-777607 (ASLAN002) } \\
\text { RON and c-Met ATP-competitive } \\
\text { inhibitor }\end{array}$ & 1 & Safety & $\begin{array}{l}\text { Advanced or metastatic } \\
\text { solid tumors }\end{array}$ & $\begin{array}{c}\text { Oral daily doses of } \\
100 \mathrm{mg}, 200 \mathrm{mg}, 300 \mathrm{mg}, 450 \\
\mathrm{mg} \text {, or } 600 \mathrm{mg}\end{array}$ & $\begin{array}{c}\text { NCT01721148 } \\
\text { Status: Completed } \\
\text { Safety profile acceptable } \\
\text { Down-modulation of a RON } \\
\text { biomarker (CTX) found [30] }\end{array}$ \\
\hline $\begin{array}{c}\text { Volitinib (HMPL-504) } \\
\text { c-Met ATP-competitive inhibitor }\end{array}$ & 1 & Safety/efficacy & Advanced solid tumors & $\begin{array}{l}\text { Oral tablet of } 25 \mathrm{mg}, 100 \mathrm{mg} \\
\text { and } 200 \mathrm{mg} \text {, once daily or } \\
2 \text { times a day }\end{array}$ & $\begin{array}{c}\text { NCT01985555 } \\
\text { Status: Active } \\
\text { Patients with c-Met dysregulation } \\
\text { showed responses [31] }\end{array}$ \\
\hline Volitinib & 1 & Safety, PK, Efficacy & $\begin{array}{l}\text { EGFR mutation-positive } \\
\text { NSCLC patients who } \\
\text { progressed on EGFR } \\
\text { tyrosine kinase inhibitor }\end{array}$ & $\begin{array}{c}\text { Volitinib at } 600 \text { or } 800 \mathrm{mg} \text { orally } \\
\text { once daily } \\
\text { Gefitinib at } 250 \mathrm{mg} \text { orally } \\
\text { once daily }\end{array}$ & $\begin{array}{c}\text { NCT02374645 } \\
\text { Status: Active, not recruiting }\end{array}$ \\
\hline $\begin{array}{c}\text { Tepotinib (EMD1214063) } \\
\text { c-Met ATP-competitive inhibitor } \\
\text { plus Gefitinib (EGFR TKI) }\end{array}$ & 2 & Efficacy & Advanced NSCLC & $\begin{array}{l}\text { Tepotinib at } 300 \text { or } 500 \mathrm{mg} \\
\text { orally once daily over a } \\
21 \text {-day cycle } \\
\text { Gefitinib at } 250 \text { mg orally once } \\
\text { daily over a } 21 \text {-day cycle }\end{array}$ & $\begin{array}{c}\text { NCT01982955 } \\
\text { Status: Active, not recruiting }\end{array}$ \\
\hline
\end{tabular}


Table 1. Cont

\begin{tabular}{|c|c|c|c|c|c|}
\hline Agent(s) and Mechanism & Trial Phase & Endpoints & $\begin{array}{c}\text { Patient } \\
\text { Population/Indication }\end{array}$ & Study Design & $\begin{array}{l}\text { Clinical Trial Identifier and Status } \\
\text { Source: } w w w . \text { Clinicaltrials.gov }\end{array}$ \\
\hline Tepotinib & 2 & Efficacy/Safety & $\begin{array}{l}\text { Advanced NSCLC with } \\
\text { MET Exon } 14 \text { Skipping } \\
\text { Alterations }\end{array}$ & $\begin{array}{l}500 \mathrm{mg} \text { once orally daily in } \\
\text { 21-day cycles }\end{array}$ & $\begin{array}{c}\text { NCT02864992 } \\
\text { Status: Recruiting }\end{array}$ \\
\hline $\begin{array}{c}\text { Foretinib (GSK1363089) } \\
\text { multi-kinase ATP-competitive } \\
\text { inhibitor of c-Met and VEGFRs } \\
\text { plus Erlotinib (EGFR TKI) }\end{array}$ & 1 & Safety & $\begin{array}{l}\text { Previously treated } \\
\text { advanced NSCLC } \\
\text { unselected for EGFR } \\
\text { genotype }\end{array}$ & $\begin{array}{c}150 \mathrm{mg} \text { erlotinib once daily and } \\
30-45 \mathrm{mg} \text { foretinib added on } \\
\text { day } 15 \text { of cycle } 1\end{array}$ & $\begin{array}{l}\text { NCT01068587 } \\
\text { Status: Completed Responses seen in } \\
\text { 17.8\% of evaluable patients. Baseline } \\
\text { c-Met expression associated with } \\
\text { response. Incremental toxicity } \\
\text { seen [32] }\end{array}$ \\
\hline $\begin{array}{c}\text { Glesatinib (MGCD265) } \\
\text { c-Met and multiple kinase } \\
\text { ATP-competitive inhibitor } \\
\text { plus Nivolumab (PD-1 blocker) }\end{array}$ & 2 & Safety/Efficacy & $\begin{array}{l}\text { Advanced NSCLC, } \\
\text { previously treated with } \\
\text { platinum doublet } \\
\text { chemotherapy and a } \\
\text { checkpoint inhibitor }\end{array}$ & $\begin{array}{l}\text { Twice daily oral glesatinib } \\
\text { (two doses tested) } \\
\text { Nivolumab } 240 \text { mg IV every } \\
2 \text { weeks }\end{array}$ & $\begin{array}{l}\text { NCT02954991 } \\
\text { Status: Recruiting }\end{array}$ \\
\hline $\begin{array}{c}\text { SAR125844 } \\
\text { c-Met selective ATP-competitive } \\
\text { inhibitor }\end{array}$ & 1 & $\begin{array}{c}\text { Safety, PK, } \\
\text { Preliminary Efficacy }\end{array}$ & $\begin{array}{l}\text { Advanced solid tumors } \\
\text { with MET amplification or } \\
\text { phospho-c-Met expression }\end{array}$ & $\begin{array}{l}\text { Escalating doses }(50-740 \\
\mathrm{mg} / \mathrm{m}^{2} \text { ) given IV weekly for } 6 \\
\text { weeks or until progression }\end{array}$ & $\begin{array}{c}\text { NCT02435121 } \\
\text { Status: Completed } \\
\text { Drug was well tolerated and } \\
\text { anti-tumor activity was observed } \\
\text { only in MET amplified patients [33] }\end{array}$ \\
\hline $\begin{array}{c}\text { Emibetuzumab (LY2875358) } \\
\text { anti-c-Met bivalent antibody } \\
\text { plus Ramucirumab (anti-VEGFR2 } \\
\text { antibody) }\end{array}$ & 1 & Safety & $\begin{array}{l}\text { Advanced or metastatic } \\
\text { solid tumors }\end{array}$ & $\begin{array}{l}\text { Dose escalation of IV } \\
\text { emibetuzumab, in combination } \\
\text { with a fixed dose of IV } \\
\text { ramucirumab on days } 1 \text { and } 15 \\
\text { of every } 28 \text { day cycle }\end{array}$ & $\begin{array}{c}\text { NCT02082210 } \\
\text { Status: Active, not recruiting }\end{array}$ \\
\hline $\begin{array}{l}\text { Emibetuzumab } \\
\text { Plus Erlotinib }\end{array}$ & 22 & Efficacy & $\begin{array}{l}\text { NSCLC with activating } \\
\text { EGFR mutations }\end{array}$ & $\begin{array}{l}\text { Lead In: } 8 \text { weeks of oral daily } \\
\text { Erlotinib, } 150 \mathrm{mg} \\
\text { Randomization: } \\
\text { Emibetuzumab }(20 \mathrm{mg}) \text { given } \\
\text { IV on Days } 1 \text { and } 15 \text { of } 28 \text {-day } \\
\text { cycles, with and without } \\
\text { Erlotinib. }\end{array}$ & $\begin{array}{c}\text { NCT01897480 } \\
\text { Status: Active, not recruiting }\end{array}$ \\
\hline
\end{tabular}


Table 1. Cont

\begin{tabular}{|c|c|c|c|c|c|}
\hline Agent(s) and Mechanism & Trial Phase & Endpoints & $\begin{array}{c}\text { Patient } \\
\text { Population/Indication }\end{array}$ & Study Design & $\begin{array}{l}\text { Clinical Trial Identifier and Status } \\
\text { Source: } w w w . \text { Clinicaltrials.gov }\end{array}$ \\
\hline $\begin{array}{l}\text { Rilotumumab (AMG 102) } \\
\text { Human IgG2 monoclonal } \\
\text { neutralizing antibody to HGF }\end{array}$ & 22 & Efficacy & Stage IV SCLC & $\begin{array}{c}\text { Rilotumumab } 15 \mathrm{mg} / \mathrm{kg} \text { given } \\
\text { with etoposide and carboplatin } \\
\text { or cisplatin }\end{array}$ & $\begin{array}{c}\text { NCT00791154 } \\
\text { Status: Completed } \\
\text { Outcomes not improved although } \\
\text { low HGF levels associated with } \\
\text { improved survival [34] }\end{array}$ \\
\hline $\begin{array}{c}\text { YYB-101 } \\
\text { Neutralizing humanized } \\
\text { monoclonal Ab against HGF }\end{array}$ & 11 & Safety/Efficacy & Solid tumors & $\begin{array}{c}\text { Increasing dose }(0.3 \mathrm{mg} / \mathrm{kg} \text { to } 5 \\
\mathrm{mg} / \mathrm{kg}) \text {, IV on Day } 1 \text { and Day } \\
29 \text {, followed by every } 2 \text { weeks. } \\
\text { Dose-expansion cohort: MTD } \\
\text { (or RP2D), IV infusion every } \\
2 \text { weeks }\end{array}$ & $\begin{array}{c}\text { NCT02499224 } \\
\text { Status: Recruiting }\end{array}$ \\
\hline $\begin{array}{c}\text { Ficlatuzumab (AV-299) } \\
\text { humanized IgG1 monoclonal } \\
\text { antibody against HGFplus } \\
\text { Gefitinib }\end{array}$ & $1 b$ & Safety/Efficacy & $\begin{array}{c}\text { Asian NSCLC patients, } \\
\text { unselected for EGFR } \\
\text { mutation }\end{array}$ & $\begin{array}{l}\text { Ficlatuzumab } 10 \mathrm{mg} / \mathrm{kg} \text { or } \\
\qquad 20 \mathrm{mg} / \mathrm{kg} \\
\text { IV on days } 1 \text { and } 15 \text { of a } \\
28 \text { day cycle. } \\
\text { Gefitinb } 250 \mathrm{mg} \text { orally daily }\end{array}$ & $\begin{array}{c}\text { NCT } \\
\text { Status: Completed } \\
\text { Dose-related activity seen in patients } \\
\text { with no prior EGFR TKI treatment, } \\
\text { some in EGFR WT patients [35] }\end{array}$ \\
\hline $\begin{array}{c}\text { TAK-701 } \\
\text { humanized monoclonal antibody } \\
\text { to HGF }\end{array}$ & 11 & Safety/Efficacy & Advanced solid tumors & $\begin{array}{c}2,5,10, \text { or } 20 \mathrm{mg} / \mathrm{kg} \text { IV. Cycle } 1: \\
\text { single dose at } 2 \mathrm{x} \text { the dose } \\
\text { assignment; Cycle } 2 \text { and } \\
\text { beyond: dose once every } \\
\text { two weeks }\end{array}$ & $\begin{array}{c}\text { NCT00831896 } \\
\text { Status: Completed } \\
\text { TAK-701 was well tolerated [36] }\end{array}$ \\
\hline $\begin{array}{l}\text { SAIT301 } \\
\text { Monoclonal Ab against c-Met } \\
\text { that induces c-Met degradation }\end{array}$ & 11 & Safety/Efficacy & Solid tumors & $\begin{array}{l}8 \text { cohorts comprised of } 3 \text { to } 6 \\
\text { subjects each. SAIT301 will be } \\
\text { administered according to a } 3+ \\
3 \text { design }\end{array}$ & $\begin{array}{l}\text { NCT02296879 } \\
\text { Status: Completed, } \\
\text { No results posted }\end{array}$ \\
\hline $\begin{array}{c}\text { LY3164530 } \\
\text { c-Met/EGFR bispecific antibody }\end{array}$ & 11 & Safety/Efficacy & Solid tumors & $\begin{array}{l}\text { LY3164530 in escalating dose } \\
\text { cohorts given IV once on Days } \\
1,8,15 \text {, and } 22 \text { of a } 28 \text {-day cycle }\end{array}$ & $\begin{array}{l}\text { NCT02221882 } \\
\text { Status: Completed, } \\
\text { No results posted }\end{array}$ \\
\hline $\begin{array}{c}\text { JNJ-61186372 } \\
\text { c-Met/EGFR bispecific antibody }\end{array}$ & 11 & Safety/Efficacy & NSCLC & $\begin{array}{l}\text { Increasing dose levels for } 28 \\
\text { day cycles. The dose will be } \\
\text { escalated until the MDT }\end{array}$ & $\begin{array}{l}\text { NCT02609776 } \\
\text { Status: Recruiting }\end{array}$ \\
\hline
\end{tabular}


Table 1. Cont

\begin{tabular}{|c|c|c|c|c|c|}
\hline Agent(s) and Mechanism & Trial Phase & Endpoints & $\begin{array}{c}\text { Patient } \\
\text { Population/Indication }\end{array}$ & Study Design & $\begin{array}{l}\text { Clinical Trial Identifier and Status } \\
\text { Source: } w w w . C l i n i c a l t r i a l s . g o v\end{array}$ \\
\hline $\begin{array}{c}\text { ARGX-111 } \\
\text { c-Met-targeting human } \\
\text { monoclonal Ab that activates } \\
\text { antibody-dependent cellular } \\
\text { cytotoxicity }\end{array}$ & 11 & Safety/Efficacy & $\begin{array}{l}\text { c-MET-overexpressing } \\
\text { cancer }\end{array}$ & $\begin{array}{c}\text { Doses given were- } 0.3 \mathrm{mg} / \mathrm{kg} \text {, } \\
1.0 \mathrm{mg} / \mathrm{kg}, 3.0 \mathrm{mg} / \mathrm{kg} \text { and } \\
10 \mathrm{mg} / \mathrm{kg}\end{array}$ & $\begin{array}{c}\text { NCT02055066 } \\
\text { Status: Completed } \\
\text { Good safety profile, some activity } \\
\text { in patients with } \\
\text { c-Met abnormalities [37] }\end{array}$ \\
\hline $\begin{array}{c}\text { MP0250 } \\
\begin{array}{c}\text { Dual anti-HGF/anti-VEGF } \\
\text { antibody mimetic }\end{array}\end{array}$ & 22 & Safety/Efficacy & Advanced solid tumors & $\begin{array}{l}\text { IV infusion at up to six dose } \\
\text { levels, every other week for up } \\
\text { to } 24 \text { infusions }\end{array}$ & $\begin{array}{c}\text { NCT02194426 } \\
\text { Status: Active, Not recruiting }\end{array}$ \\
\hline $\begin{array}{c}\text { ABT-700 } \\
\text { c-Met } \\
\text { monoclonal antibody }\end{array}$ & 11 & Safety/efficacy & $\begin{array}{l}\text { Advanced solid tumors } \\
\text { with MET amplification or } \\
\text { overexpression }\end{array}$ & $\begin{array}{l}\text { IV infusion at escalating doses } \\
\text { in 21-day cycles } \\
\text { ABT-700 will also be given in } \\
\text { combination with other } \\
\text { therapies in } 3 \text { cohorts }\end{array}$ & $\begin{array}{l}\text { NCT01472016 } \\
\text { Status: Completed } \\
\text { No results posted }\end{array}$ \\
\hline
\end{tabular}




\section{Crizotinib: First Generation c-Met Tyrosine Kinase Inhibitor}

Synthetic small-molecule c-Met TKIs are low molecular weight molecules that compete for the adenosine triphosphate (ATP) binding site of the c-Met tyrosine kinase domain [20]. This prevents activation of the receptor and arrests downstream signaling. Several small molecules that target c-Met show a lack of specificity and can also impede the ATP binding site in other kinases such as vascular endothelial growth factor receptor (VEGFR) and the translocated EML4-anaplastic lymphoma kinase (ALK). Crizotinib (PF-02341066) is a compound developed to target c-Met that also showed a high affinity for the translocated ALK fusion protein. In preclinical studies, crizotinib successfully suppressed NSCLC cell growth, migration and cell survival in models that expressed c-Met $[13,20]$. This compound has shown efficacy at well tolerated doses in NSCLC patients in patients with amplified or mutated c-Met, and in those with ALK abnormalities, but had little activity in NSCLC without these abnormalities [8]. In a phase III trial of first-line treatment in ALK (Anaplastic Lymphoma Kinase) Positive East Asian NSCLC with an ALK translocation or inversion, crizotinib was found to improve progression free survival (median 11.1 months), as compared to chemotherapy (median 6.8 months) [38] which led to its rapid FDA approval for ALK positive disease.

\section{Tyrosine Kinase Inhibitors with Selectivity for c-Met}

Volitinib (Savolitinib) is a selective c-Met inhibitor that blocks c-Met activity in an ATP-dependent manner. It has been shown to have anti-tumor activity in gastric and papillary renal carcinoma $[39,40]$ in xenograft models. More recently in preclinical studies, it has been reported to inhibit tumor growth in NSCLC by blocking the PI3K/AKT, MAPK signaling and c-Myc down regulation [41]. Intravenous delivery of volitinib in gastric cancer models with amplification of the MET gene showed dose-dependent tumor regression [39]. Volitinib is being tested in combination with gefitinb in EGFR mutant NSCLC (Table 1).

SAR125844: This derivative of triazolopyridazine was first identified as a selective inhibitor of both wild type c-Met and c-Met with kinase domain mutations in gastric cancer cell lines. Xenograft studies with MET amplified gastric tumor cells showed significant tumor growth inhibition because of antiproliferative and proapoptotic effects of the drug and down regulation of PI3K/AKT and RAS/MAPK pathways [42]. Pharmacokinetics studies were performed and analyzed in several species from mice to dog [43]. Phase I dose escalation and dose expansion study in patients with advanced tumors showed modest antitumor response in patients with MET amplified gastric cancers at $570 \mathrm{mg} / \mathrm{m}^{2}$ and was well tolerated [44]. A first in human phase 1 clinical trial was performed in patients with NSCLC (Table 1). The cohort included MET amplified, high c-Met, and high phospho-c-Met patients. No response was observed in patients with high c-Met; however significant antitumor response at $570 \mathrm{mg} / \mathrm{m}^{2}$ was observed in patients with MET amplification [33].

Tepotinib (EMD1214063) is a c-Met inhibitor with $\geq 1000$ fold selectivity for c-Met as compared to other kinases. It inhibited both HGF-dependent and HGF-independent c-Met phosphorylation in vitro in lung and gastric cancer cell lines and showed tumor regression in xenografts model [45]. Tepotinib has been shown to overcome the acquired resistance to first generation EGFR TKIs in NSCLC with T790M mutation, displaying complete regression in xenograft studies when combined with rocelitinib, a third generation EGFR TKI that targets the T790M mutation [46]. Phase $1 \mathrm{~b} / 2$ trial of tepotinib combined with gefitinib is on ongoing clinical study (NCT01982955) to evaluate the efficacy in terms of progression-free survival in advanced lung cancer (Table 1). Tepotinib is also being evaluated in a phase II single arm clinical trial in patients with advanced (stage III/IV) NSCLC harboring MET exon 14 skipping mutation (NCT02864992, Table 1).

Capmatinib (INCB28060) was identified as a very potent selective competitive inhibitor for c-Met, inhibiting activity at picomolar concentrations and displaying $\geq 10,000$ selectivity for c-Met compared to other kinases. Effective anti-proliferative and anti-apoptotic properties of capmatinib were observed in c-Met driven mouse tumor models [47]. In NSCLC cell lines made resistant to erlotinib through the 
addition of HGF, capamitinib could re-sensitize cells to erlotinib [48]. Clinical studies are ongoing with exon 14 mutation or MET amplification (Table 1) to establish safety and pharmacokinetics.

\section{Multi-Kinase Targeting}

An approach to improve responses to TKIs in patients lacking specific genetic alterations is to broaden the kinases being targeted. A number of TKIs are being tested clinically with ability to block multiple receptors (Table 1). Foretinib (XL-880) inhibits several kinases including c-Met, RON, VEGFR2, KIT, TIE2 and PDGFR [32], suggesting it could block proliferation and be anti-angiogenic. Foretinib was tested in a phase I trial given with erlotinib in NSCLC patients who progressed after chemotherapy. Responses were seen in $17.8 \%$ of evaluable patients, including those without EGFR mutation. Baseline c-Met expression was associated with response, suggesting combining this multi-kinase inhibitor with an EGFR inhibitor could improve sensitivity to erlotinib in both EGFR mutant and wild type patients. Cabozantinib (XL-184) is another multi-kinase inhibitor that targets c-Met, VEGFR1, VEGFR2, VEGFR3, RET, TIE2, FLT-3 and KIT, so should block multiple pro-cancer signaling pathways [49]. It has significant oral bioavailability and blood-brain barrier penetration. It was found to be superior to erlotinib and to improve outcomes when combined with erlotinib in patients who lacked EGFR mutations, with acceptable toxicity [49].

The multi-kinase inhibitor glesatinib (MGCD265) targets c-Met, VEGFR1, VEGFR2, VEGFR3, TIE2 and RON [50]. It is currently being tested in clinical trials for NSCLC in combination with erlotinib and docetaxel. A Phase 2 trial of glesatinib in combination with the checkpoint blocker nivolumab in patients with advanced NSCLC previously treated with platinum doublet chemotherapy and a checkpoint inhibitor is ongoing (Table 1). Another agent that targets both c-Met and RON, BMS-777607, showed an acceptable safety profile in a phase 1 trial, and a RON biomarker, CTX, was down-modulated by the drug [30].

\section{Biological Antagonists of HGF or c-Met}

Several types of biological antagonists have been developed that either neutralize HGF, c-Met, or the HGF-c-Met interaction. These agents are in various stages of development and can be used as a monotherapy or in combination with other targeted therapies. HGF-competitive analogs compete with the ligand for receptor binding on the cell surface. They do not lead to c-Met signaling and cannot induce c-Met dimerization, while HGF neutralizing antibodies bind to the fully processed HGF molecule, preventing interaction of HGF with the receptor. c-Met competitive variants competitively displace HGF and do not cause dimerization of the receptor. Decoys of c-Met have also been produced that bind to intact c-Met or HGF to disrupt dimerization of native c-Met receptor [51].

The following biological antagonists have been, or are currently being, clinically evaluated:

Onartuzumab (MetMAb): Onartuzumab is a monoclonal antibody against c-Met that obstructs the binding of the HGF $\alpha$-chain to its c-Met ligand binding domain [52]. After safety evaluation [53], a phase II trial showed increased efficacy of onartuzumab in combination with erlotinib compared to erlotinib alone $\mathrm{n}$ patients positive for $\mathrm{c}-$ Met protein by immunohistochemical evaluation [54,55]; however further testing in a phase III trial was discontinued for lack of efficacy in this setting, in which the combination with erlotinib showed shorter survival [56].

Emibetuzumab (LY2875358): Emibetuzumab is a bivalent antibody raised against c-Met that blocks HGF binding to c-Met, preventing signaling. Unlike onartuzumab, it leads to internalization and degradation of c-Met. In a study using mouse xenograft models, emibetuzumab blocked both HGF-dependent and -independent tumor growth [57]. A phase I clinical trial with emibetuzumab alone or in combination with erlotinib was carried out in patients with NSCLC [58]. 23 patients received emibetuzumab alone, one patient experienced a partial response (4.3\%) and five patients $(21.7 \%)$ experienced stable disease. Out of the 14 NSCLC patients receiving combination treatment, two patients experienced a partial response $(14.3 \%)$ and four $(28.6 \%)$ had stable disease. Comparing 
emibetuzumb with and without erlotinib is now being tested in a phase 2 trial, and it is also currently being tested in a phase 1 trial in combination with an anti-VEGFR2 antibody, ramucirumab (Table 1).

LY3164530 is a bispecific monoclonal antibody that binds and degrades both c-Met and EGFR, which has shown strong ability to inhibit signaling from both receptors. In a xenograft model [59], LY3164530 had more anti-tumor effect in comparison to emibetuzumab and cetuximab, and was effective against NSCLC resistant to EGFR inhibitors [60]. It is now in phase 1 testing (Table 1).

JNJ-61186372: The anti-tumor activity of JNJ-61186372, a c-Met and EGFR bispecific antibody, was investigated in in vitro and in vivo studies involving NSCLC tumor models, and showed strong ability to reduce tumor growth [61,62]. The safety and efficacy of JNJ-61186372 are currently being evaluated in a Phase 1 study in NSCLC (Table 1), to determine dosing for phase 2 studies and to identify any dose limiting toxicities. The study is scheduled for completion in 2020.

SAIT301: This is a humanized monoclonal antibody that targets the alpha chain of the extracellular domain of c-Met [63], preventing HGF binding. In addition, SAIT301 causes c-Met internalization that leads to degradation, which enhances the blockade of c-Met signaling. [63]. There is an ongoing phase I clinical study for patients with c-Met-positive solid tumors, using immunohistochemistry to detect positive c-Met staining (Table 1).

ABT-700 (h224G11): The anti-c-Met monoclonal antibody ABT-700 has anti-tumor effects in lung cancer xenografts with amplification of MET gene [64]. An ongoing phase I study of ABT-700 alone or in combination with one of three standard-of-care regimens is comparing the efficacy of monotherapy $\mathrm{v} / \mathrm{s}$ combinational therapy in advanced solid tumors with MET gene amplification and/or c-Met overexpression (Table 1).

Rilotumumab (AMG-102): Rilotumumab was the first HGF inhibitor to reach phase 3 clinical testing. It binds to the HGF $\beta$-chain, inhibiting HGF binding to c-Met [65]. Rilotumumab showed tolerability in the phase 1 clinical trial [66]. In the phase 2 study, addition of rilotumumab to capecitabine, cisplatin and epirubicin led to an increase in progression free survival and overall survival in MET-positive patients with adenocarcinoma [66]. However, there were two phase 3 clinical trials that showed negative results. For example, the RILOMET-1 study was stopped early (in 2014) because of lower efficacy, higher toxicity, shorter overall survival and lack of specific effects in NSCLC patients with $M E T$ amplification [67]. Rilotumumab was evaluated in combination with chemotherapy for small cell lung cancer. Overall survival was better with rilotumumab (10.8 months in placebo arm vs. 12.2 months in the rilotumumab arm) [34]. Rilotumumab was also tested in combination with erlotinib in a phase 1/2 study in NSCLC patients unselected for EGFR mutations status; the combination was found to have an acceptable safety profile. The disease control rate (DCR) for all patients was $60 \%$. Among patients with wild type EGFR, the DCR was $60.6 \%$ and median overall survival was 7.0 months (90\% CI, 5.6-13.4 months) [68], suggesting that blocking HGF in combination with an EGFR TKI might improve efficacy in the EGFR wild-type population.

Ficlatuzumab (AV-299): Ficlatuzumab is a humanized anti-HGF neutralizing antibody. In a phase I trial, ficlatuzumab alone had a maximum tolerance dose of $20 \mathrm{mg} / \mathrm{kg}$ in patients with NSCLC. The toxicities observed were low grade [69]. There was an increase in circulating HGF observed in patients after ficlatuzumab treatment, compared to the basal levels, suggesting a rebound effect occurs that could limit efficacy [70]. Results from a phase II study compared the efficacy of ficlatuzumab and gefitinib in combination versus gefitinib as monotherapy in Asian patients with lung adenocarcinoma. There was no significant difference in response rate observed in monotherapy (40\%) compared to combination therapy $(43 \%)$, or in progression-free survival (4.7 months in monotherapy vs. 5.6 months in combinational therapy) [71]. However, patients who were classified as VeriStrat-poor (a test for erlotinib sensitivity) had better outcomes with the combination, and might benefit from ficlatuzumab.

TAK-701: This humanized monoclonal antibody against HGF was active in overcoming gefitinib resistance observed in EGFR-mutant human NSCLC cells [72]. During a phase I study in patients with advanced solid malignancies, TAK-701 had a good safety profile, with only low grade adverse effects [72]. YYB-101 is a neutralizing monoclonal antibody against HGF. It binds to the HGF $\alpha$-chain 
and blocks c-Met activation and cell metastasis in vitro. It also has an anti-tumor effect in several xenografts [73,74]. There is an ongoing phase I clinical study in patients with advanced solid tumors.

ARGX-111 is a c-Met targeting human monoclonal that elicits antibody-dependent cellular cytotoxicity as part of its mechanism of action. A phase 1 study [37] showed a good safety profile and some activity in patients with c-Met abnormalities. MP0250 is a dual-specific antibody mimetic (a designed ankyrin repeat protein (DARPin ${ }^{\circledR}$ ) that functions as a neutralizing protein for both VEGF and HGF [75]. It contains two human serum albumin antibody mimic sequences that flank an anti-HGF and an anti-VEGF sequence, producing a moiety that binds and neutralizes both VEGF and HGF [75]. The rationale for dual targeting is the observation of up-regulation of the VEGF pathway when c-Met is inhibited [75]. MP0250 has shown preclinical activity against human patient-derived xenografts with HGF expression [75], and is being tested in a phase 2 clinical trial in solid tumors (Table 1).

DN30: This c-Met antibody under development for clinical use acts through several novel mechanisms to disrupt c-Met signaling, including causing degradation of the receptor. The mechanism of action of DN30 involves down-regulation of c-Met, in which receptor bound to DN30 at the cell surface is removed by proteolytic cleavage, resulting in shedding of the extracellular domain [76]. The cleaved c-Met fragment acts as a decoy receptor because a functional HGF binding site is still present, and the cleaved portion is able to sequester free HGF, as well as dimerize with any intact active c-Met receptors remaining on the cell surface. Both these actions render c-Met inactive by preventing homodimerization of intact c-Met receptors, or by forming nonfunctional heterodimers $[77,78]$. By this dual mechanism, DN30 efficiently blocks both HGF binding and c-Met phosphorylation, showing activities found in both TKIs and neutralizing antibodies [79]. The combined effect is that DN30 can block both the HGF-dependent and HGF-independent pathways. It showed anti-cancer effects in both in vitro and in vivo models of tumors with addiction to the c-Met pathway [79].

\section{Mechanisms of Resistance to Inhibitors of the HGF/c-Met Axis}

Multiple gene mutations and mechanisms are known to contribute to resistance to HGF/c-Met pathway blockade, such as HER, BRAF and KRAS pathways, or mutations in c-Met $[80,81]$. For example, in preclinical studies, there was maintenance of downstream PI3K and MAPK signaling by emergence of a mutation in the c-Met activation loop (Y1230), avoiding an interaction with a c-MET TKI; activation of the EGFR pathway through secretion of transforming growth factor $\alpha$ also was a resistance mechanism [81]. NSCLC models showed that resistance to anti-MET agents was accompanied by upregulation of the Wnt and mTOR pathways [82]. Increased HGF secreted into the microenvironment can also overcome the action of anti-MET drugs and convert genetically altered constitutively active c-Met tumors into ligand-dependent tumors [83]. Proposed strategies that can be used to overcome acquired resistance in patients with basal sensitivity to HGF/c-Met pathway inhibition include adding inhibitors at different upstream and downstream levels of the pathway, adding an HGF neutralizing antibody to a c-Met targeting drug, and using upfront drug combinations to circumvent bypass mechanisms.

\section{Role of HGF-c-Met in Resistance to Other Therapies}

The tumor microenvironment is engaged in resistance to molecular-targeted therapies. Stromal cells influence the action of cancer therapeutics, and stromal changes such as release of HGF can provide an alternate stimulus when other pathways are blocked. In a study using a RAF inhibitor, increased HGF secretion was identified as a prime mechanism for resistance [84]. Although the T790M second mutation in the mutant EGFR often occurs in NSCLC patients with acquired resistance to EGFR TKIs [85], HGF-dependent c-Met activation and constitutive activation by amplification of the MET gene are noted compensatory mechanisms that also are factors in acquired resistance in EGFR mutant NSCLC patients $[86,87]$. Alectinib, a selective anaplastic lymphoma kinase (ALK) TKI that lacks interaction with c-Met, has high activity in ALK mutant NSCLC patients; alcetinib treatment in 
ALK positive patients was associated with increased median progression free survival and high response rate [88]. However, many NSCLC patients eventually became resistant to alectinib and one common mechanism of acquired resistance to ALK TKIs is the secretion of HGF into the tumor microenvironment, leading to HGF-dependent c-Met signaling [89]. This is another example of how over-activity of the c-Met pathway is an important escape mechanism in targeted therapy resistance.

\section{Conclusions}

Although the c-Met pathway is frequently overactive in NSCLC, inhibiting either the c-Met receptor itself or its ligand HGF has not proven effective as single therapy in unselected NSCLC patients. Clinical response to these agents has to date been largely restricted to NSCLC patients with genetic alterations in $M E T$, such as amplification or exon 14 deletion. Some patients with acquired EGFR TKI drug resistance that involves up-regulation of the c-Met pathway also have responded. Acquired resistance that eventually develops after initial response to c-Met pathway inhibitors often involves activation of parallel signaling pathways or induction of HGF secretion. Several new classes of HGF/c-Met inhibitors may show expanded activity in patients with MET genetic alterations, and might also prove effective in NSCLC with overexpressed c-Met in the absence of genetic abnormality. These include the multi-kinase inhibitors that block c-Met as well as a range of other kinases; the kinase inhibitors and monoclonal antibodies against c-Met that also cause degradation of the c-Met protein; and the bivalent antibodies that can block several pathways simultaneously. The newer c-Met TKIs with improved c-Met selectivity compared to earlier agents most likely will only be active as single agents in the presence of MET oncogene addiction. Combinations of kinase inhibitors that target both upstream and downstream in the signaling pathway, or reduce parallel kinase signaling from other receptors, could improve clinical benefit, but toxicity has been a problem with these targeted combinations in the past. Combining a c-Met TKI or antibody with an HGF neutralizing antibody may improve efficacy. Other approaches to expand efficacy of HGF/c-Met targeting include combining these agents with inhibitors of the viability or function of stromal cells such as tumor-associated fibroblasts, endothelial cells, or macrophages, or using immunotherapy in combination with HGF/c-Met agents. Such strategies might also increase activity of these drugs in a wider range of patients who lack MET genetic abnormalities.

Author Contributions: Conceptualization: J.M.S. and O.M. Literature Searches: J.M.S., O.M., M.F. WritingOriginal Draft: O.M. Writing-Review and Editing, J.M.S., M.F.

Funding: This manuscript preparation received no external funding.

Conflicts of Interest: The authors declare no conflict of interest.

\section{References}

1. Bottaro, D.P.; Rubin, J.S.; Faletto, D.L.; Chan, A.M.; Kmiecik, T.E.; Vande Woude, G.F.; Aaronson, S.A. Identification of the hepatocyte growth factor receptor as the c-met proto-oncogene product. Science 1991, 251, 802-804. [CrossRef] [PubMed]

2. Basile, J.R.; Afkhami, T.; Gutkind, J.S. Semaphorin 4D/plexin-B1 induces endothelial cell migration through the activation of PYK2, Src, and the phosphatidylinositol 3-kinase-Akt pathway. Mol. Cell Biol. 2005, 25, 6889-6898. [CrossRef] [PubMed]

3. Tokunou, M.; Niki, T.; Eguchi, K.; Iba, S.; Tsuda, H.; Yamada, T.; Matsuno, Y.; Kondo, H.; Imamura, H.; Hirohashi, S. c-MET expression in myofibroblasts: Role in autocrine activation and prognostic significance in adenocarcinoma. Am. J. Pathol. 2001, 158, 1451-1463. [CrossRef]

4. Lokker, N.A.; Mark, M.R.; Luis, E.A.; Bennett, G.L.; Robbins, K.A.; Baker, J.B.; Gowdowski, P.J. Structure-function analysis of hepatocyte growth factor: Identification of variants that lack mitogenic activity yet retain high affinity receptor binding. EMBO J. 1992, 11, 2503-2510. [PubMed]

5. Gherardi, E.; Sandin, S.; Petoukhov, M.V.; Finch, J.; Youles, M.E.; Ofverstedt, L.G.; Miguel, R.N.; Blundell, T.L.; Vande Woude, G.F.; Skoglund, U.; et al. Structural basis of hepatocyte growth factor/scatter factor and MET signalling. Proc. Natl. Acad. Sci. USA 2006, 103, 4046-4051. [CrossRef] [PubMed] 
6. Zhang, Y.W.; Vande Woude, G.F. HGF/SF-met signaling in the control of branching morphogenesis and invasion. J. Cell Biochem. 2003, 88, 408-417. [CrossRef] [PubMed]

7. Rosario, M.; Birchmeier, W. How to make tubes: Signaling by the Met receptor tyrosine kinase. Trends Cell Biol. 2003, 13, 328-335. [CrossRef]

8. Corso, S.; Comoglio, P.M.; Giordano, S. Cancer therapy: Can the challenge be MET? Trends Mol. Med. 2005, 11, 284-292. [CrossRef] [PubMed]

9. Boccaccio, C.; Comoglio, P.M. Invasive growth: A MET-driven genetic programme for cancer and stem cells. Nat. Rev. Cancer 2006, 6, 637-645. [CrossRef] [PubMed]

10. Ma, P.C.; Kijima, T.; Maulik, G.; Fox, E.A.; Sattler, M.; Griffin, J.D. C-MET mutational analysis in small cell lung cancer: Novel juxtamembrane domain mutations regulating cytoskeletal functions. Cancer Res. 2003, 63, 6272-6281. [PubMed]

11. Dulak, A.M.; Gubish, C.T.; Stabile, L.P.; Henry, C.; Siegfried, J.M. HGF-independent potentiation of EGFR action of c-Met. Oncogene 2011, 30, 3625-3635. [CrossRef] [PubMed]

12. Stabile, L.P.; Rothstein, M.E.; Keohavong, P.; Jin, J.; Yin, J.; Land, S.R. Therapeutic targeting of human hepatocyte growth factor with a single neutralizing monoclonal antibody reduces lung tumorigenesis. Mol. Cancer Ther. 2008, 7, 1913-1922. [CrossRef] [PubMed]

13. Puri, N.; Salgia, R. Synergism of EGFR and c-Met pathways, cross-talk and inhibition, in non-small cell lung cancer. J. Carcinog. 2008, 7, 9. [CrossRef] [PubMed]

14. Shattuck, D.L.; Miller, J.K.; Carraway, K.L., 3rd; Sweeny, C. Met receptor contributes to trastuzumab resistance of Her2-overexpressing breast cancer cells. Cancer Res. 2008, 68, 1471-1477. [CrossRef] [PubMed]

15. Bauer, T.W.; Somcio, R.J.; Fan, F.; Liu, W.; Johnson, M.; Lesslie, D.P.; Evans, B.D.; Gallick, G.E.; Ellis, L.M. Regulatory role of c-Met in insulin-like growth factor-I receptor-mediated migration and invasion of human pancreatic carcinoma cells. Mol. Cancer Ther. 2006, 5, 1676-1682. [CrossRef] [PubMed]

16. Fan, S.; Meng, Q.; Laterra, J.J.; Rosen, E.M. Ras effector pathways modulate scatter factor-stimulated NFkappaB signaling and protection against DNA damage. Oncogene 2007, 26, 4774-4796. [CrossRef] [PubMed]

17. Cooke, V.G.; LeBleu, V.S.; Keskin, D.; Khan, Z.; O'Connell, J.T.; Teng, Y.; Duncan, M.B.; Xie, L.; Maeda, G.; Vong, S.; et al. Pericyte depletion results in hypoxia-associated epithelial-to-mesenchymal transition and metastasis mediated by Met signaling pathway. Cancer Cell 2012, 21, 66-81. [CrossRef] [PubMed]

18. Smolen, G.A.; Sordella, R.; Muir, B.; Mohapatra, G.; Barmettler, A.; Archibald, H.; Kim, W.J.; Okimoto, R.A.; Bell, D.W.; Sqroi, D.C.; et al. Amplification of MET may identify a subset of cancers with extreme sensitivity to the selective tyrosine kinase inhibitor PHA-665752. Proc. Natl. Acad. Sci. USA 2006, 103, 2316-2321. [PubMed]

19. Lengyel, E.; Prechtel, D.; Resau, J.H.; Gauger, K.; Welk, A.; Linderman, K.; Salanti, G.; Richter, T.; Knudsen, B.; Vade Woude, G.F.; Harbeck, N. C-Met overexpression in node-positive breast cancer identifies patients with poor clinical outcome independent of Her2/neu. Int. J. Cancer 2005, 113, 678-682. [CrossRef] [PubMed]

20. Christensen, J.G.; Burrows, J.; Salgia, R. C-Met as a target for human cancer and characterization of inhibitors for therapeutic intervention. Cancer Lett. 2005, 225, 1-26. [CrossRef] [PubMed]

21. Peschard, P.; Park, M. From Tpr-Met to Met, tumorigenesis and tubes. Oncogene 2007, 26, $1276-1285$. [CrossRef] [PubMed]

22. Danilkovitch-Miagkova, A.; Zbar, B. Dysregulation of Met receptor tyrosine kinase activity in invasive tumors. J. Clin. Investig. 2002, 109, 863-867. [CrossRef] [PubMed]

23. Ichimura, E.; Maeshima, A.; Nakajima, T.; Nakamura, T. Expression of c-met/HGF receptor in human nonsmall cell lung carcinomas in vitro and in vivo and its prognostic significance. Jpn. J. Cancer Res. 1996, 87, 1063-1069. [CrossRef] [PubMed]

24. Garcia, S.; Dalès, J.P.; Charafe-Jauffret, E.; Carpentier-Meunier, S.; Andrac-Meyer, L.; Jacquemier, J.; Andonian, C.; Lavaut, M.N.; Allasia, C.; et al. Poor prognosis in breast carcinomas correlates with increased expression of targetable CD146 and c-Met and with proteomic basal-like phenotype. Hum. Pathol. 2007, 38, 830-841. [CrossRef] [PubMed]

25. Takanami, I.; Tanana, F.; Hashizume, T.; Kikuchi, K.; Yamamoto, Y.; Yamamoto, T.; Kodaira, S. Hepatocyte growth factor and c-Met/hepatocyte growth factor receptor in pulmonary adenocarcinomas: An evaluation of their expression as prognostic markers. Oncology 1996, 53, 392-397. [CrossRef] [PubMed] 
26. Ma, P.C.; Jagadeeswaran, R.; Jagadeesh, S.; Tretiakova, M.S.; Nallasura, V.; Fox, E.A.; Hansen, M.; Schaefer, E.; Naoki, K.; Lader, A.; et al. Functional expression and mutations of c-Met and its therapeutic inhibition with SU11274 and small interfering RNA in non-small cell lung cancer. Cancer Res. 2005, 65, 1479-1488. [CrossRef] [PubMed]

27. Ozasa, H.; Oguri, T.; Maeno, K.; Takauwa, O.; Kuni, E.; Yagi, Y.; Ulemera, T.; Kasai, D.; Mizayaki, K.; Niimi, A. Significance of c-MET overexpression in cytotoxic anticancer drug-resistant small-cell lung cancer cells. Cancer 2014, 105, 1032-1039. [CrossRef] [PubMed]

28. Sakamoto, S.; Inoue, H.; Ohba, S.; Kohda, Y.; Usami, I.; Masuda, T.; Kawada, M.; Nomoto, A. New metastatic model of human small-cell lung cancer by orthotopic transplantation in mice. Cancer Sci. 2015, 106, 367-374. [CrossRef] [PubMed]

29. Taniguchi, H.; Yamada, T.; Tekeuchi, S.; Arai, S.; Fukuda, K.; Sakamoto, S.; Kawada, M.; Yamaquchi, H.; Mukae, H.; Yano, S. Impact of MET inhibition on small-cell lung cancer cells showing aberrant activation of the hepatocyte growth factor/MET pathway. Cancer Sci. 2017, 108, 1378-1385. [CrossRef] [PubMed]

30. ASLAN Pharmaceuticals. Available online: www.aslanpharma.com (accessed on 15 May 2018).

31. Gan, H.K.; Lickliter, J.; Millward, M.; Gu, Y.; Weiguo, S.U.; Frigault, M.; Qi, C.; Mu, H. First-in-human phase I study of a selective c-Met inhibitor volitinib (HMP504/AZD6094) in patients with advanced solid tumors. J. Clin. Oncol. 2014, 32, 15.

32. Leighl, N.B.; Tsao, M.S.; Liu, G.; Tu, D.; Ho, C.; Sheperd, F.A.; Murray, N.; Goffin, J.R.; Nicholar, G.; Sakashita, S.; et al. A phase I study of foretinib plus erlotinib in patients with previously treated advanced non-small cell lung cancer: Canadian cancer trials group IND.196. Oncotarget 2017, 8, 69651-69662. [CrossRef] [PubMed]

33. Angevin, E.; Spitaleri, G.; Rodon, J.; Dotti, K.; Isambert, N.; Salvagni, S.; Moreno, V.; Assadourin, S.; Gomez, C.; Hamois, M.; et al. A first-in-human phase I study of SAR125844, a selective MET tyrosine kinase inhibitor, in patients with advanced solid tumors with MET amplification. Eur. J. Cancer 2017, 87, 131-139. [CrossRef] [PubMed]

34. Glisson, B.; Besse, B.; Dols, M.C.; Dubey, S.; Schupp, M.; Jain, R.; Jiang, Y.; Menon, H.; Nackaerts, K.; Orlov, S.; et al. A randomized, Placebo-controlled, Phase 1b/2 study of Rilotumumab or Ganitumab in combination with platinum-based chemotherapy as first line treatment for extensive stage small cell lung cancer. Clin. Lung Cancer 2017, 18, 615-625. [CrossRef] [PubMed]

35. Tan, E.H.; Lim, W.T.; Ahn, M.J.; Ng, Q.S.; Ahn, J.S.; Shao-Weng Tan, D.; Sun, J.M.; Payumo, F.C.; McKee, K.; Yin, W.; et al. Phase $1 \mathrm{~b}$ trial of Ficlatuzumab, a humanized hepatocyte growth factor inhibitory monoclonal antibody, in combination with gefitinib in Asian patients with NSCLC. Clin. Pharmacol. Drug Dev. 2018, 7, 532-542. [CrossRef] [PubMed]

36. Jones, S.F.; Cohen, R.B.; Bendell, J.C.; Denlinger, C.S.; Harvey, R.D.; Parasuraman, S.; Chi, X.; Scholtz, C.; Wyant, T.; Kauh, J. Safety, tolerability, and pharmacokinetics of TAK-701, a humanized anti-hepatocyte growth factor (HGF) monoclonal antibody, in patients with advanced nonhematological malignancies: First-in-human phase I dose-escalation study. J. Clin. Oncol. 2010, 28. [CrossRef]

37. Aftimos, P.G.; Barthlemy, P.; Rolfo, C.D.; Hanssens, V.; Jonge, D.; Silence, K.; Dreier, T.; Haard, H.; Peeters, M.; Thibault, A.; et al. A Phase I, in human study of ARGX-111, a monoclonal antibody targeting c-Met in patients with Solid tumors. J. Clin. Oncol. 2015, 33, 2580. [CrossRef]

38. Kwak, E.L.; Bang, Y.J.; Camidge, D.R.; Shaw, A.T.; Solomon, B.; Maki, R.G.; Ou, S.H.; Dezube, B.J.; Janne, P.A.; Costa, D.B.; et al. Anaplastic lymphoma kinase inhibition in non-small cell lung cancer. N. Engl. J. Med. 2010, 363, 1693-1703. [CrossRef] [PubMed]

39. Gavine, P.R.; Ren, Y.; Han, L.; Lv, J.; Fan, S.; Zhang, W.; Xu, W.; Liu, Y.J.; Zhang, T.; Fu, H.; et al. Volitinib, a potent and highly selective c-Met inhibitor, effectively blocks c-Met signaling and growth in c-MET amplified gastric cancer patient-derived tumor xenograft models. Mol. Oncol. 2015, 9, 323-333. [CrossRef] [PubMed]

40. Schuller, A.G.; Barry, E.R.; Jones, R.D.; Henry, R.E.; Frigault, M.M.; Beran, G.; Linsenmayer, D.; Hattersley, M.; Smith, A.; Wilson, J.; et al. The MET Inhibitor AZD6094 (Savolitinib, HMPL-504) Induces Regression in Papillary Renal Cell Carcinoma Patient-Derived Xenograft Models. Clin. Cancer Res. 2015, 21, 2811-2819. [CrossRef] [PubMed] 
41. Henry, R.E.; Barry, E.R.; Castriotta, L.; Ladd, B.; Markovets, A.; Beran, G.; Ren, Y.; Zhou, F.; Adam, A.; Zinda, M.; et al. Acquired savolitinib resistance in non-small cell lung cancer arises via multiple mechanisms that converge on MET-independent mTOR and MYC activation. Oncotarget 2016, 7, 57651-57670. [CrossRef] [PubMed]

42. Egile, C.; Kenigsberg, M.; Delaisi, C.; Begassat, F.; Do-Vale, V.; Messtadier, J.; Bonche, F.; Benard, T.; Nicolas, J.P.; Valense, S.; et al. The selective intravenous inhibitor of the MET tyrosine kinase SAR125844 inhibits tumor growth in MET-amplified cancer. Mol. Cancer Ther. 2015, 14, 384-394. [CrossRef] [PubMed]

43. Ugolini, A.; Kenigsberg, M.; Rak, A.; Vallee, F.; Houtmann, J.; Lowinski, M.; Capdevila, C.; Khider, J.; Albert, E.; Martinet, N.; et al. Discovery and pharmacokinetic and pharmacological properties of the potent and selective MET kinase inhibitor 1-\{6-[6-(4-fluorophenyl)-[1,2,4]triazolo[4,3-b]pyridazin-3ylsulfanyl]benzothiazole-2-yl\}-3-(2-morpholin-4-ylethyl)urea (SAR125844). J. Med. Chem. 2016, 59, 7066-7074. [CrossRef] [PubMed]

44. Shitara, K.; Kim, M.; Yokota, T.; Goto, M.; Satoh, T.; Ahn, J.H.; Kim, S.H.; Assadourin, S.; Gomez, C.; Harmois, M.; et al. Phase I dose-escalation study of the c-Met tyrosine kinase inhibitor SAR125844 in Asian patients with advanced solid tumors, including patients with MET-amplified gastric cancer. Oncotarget 2017, 8, 79546-79555. [CrossRef] [PubMed]

45. Bladt, F.; Faden, B.; Friese-Hamim, M.; Knuehl, C.; Wilm, C.; Fittschen, C.; Gradler, U.; Meyring, M.; Dorsch, D.; Jaehrling, F.; et al. EMD 1214063 and EMD 1204831 constitute a new class of potent and highly selective c-Met inhibitors. Clin. Cancer Res. 2013, 19, 2941-2951. [CrossRef] [PubMed]

46. Friese-Hamim, M.; Bladt, F.; Locatelli, G.; Stammberger, U.; Blaukat, A. The selective c-Met inhibitor tepotinib can overcome epidermal growth factor receptor inhibitor resistance mediated by aberrant c-Met activation in NSCLC models. Am. J. Cancer Res. 2017, 7, 962-972. [PubMed]

47. Liu, X.; Wang, Q.; Yang, G.; Marando, C.; Koblish, H.K.; Hall, L.M.; Fridman, J.S.; Behshad, E.; Wynn, R.; Li, Y.; et al. A novel kinase inhibitor, INCB28060, blocks c-MET-dependent signaling, neoplastic activities, and cross-talk with EGFR and HER-3. Clin. Cancer Res. 2011, 17, 7127-7138. [CrossRef] [PubMed]

48. Lara, M.S.; Holland, W.S.; Chinn, D.; Bursih, R.A.; Lara, P.N.; Gandara, D.R.; Kelly, K.; Mack, P.C. Preclinical evaluation of MET inhibitor INC-280 with and without the epidermal growth factor receptor inhibitor erlotinib in non-small cell lung cancer. Clin. Lung Cancer 2017, 18, 281-285. [CrossRef] [PubMed]

49. Neal, J.W.; Dahlberg, S.E.; Wakalee, H.A.; Aisner, S.C.; Bowden, M.; Huang, Y.; Carbone, D.P.; Gerster, G.J.; Lerner, E.L.; et al. Erlotinib, cabozantinib or erlotinib plus cabozantinib as second line or third line treatment of patients with EGFR wild-type advanced non-small cell lung cancer 9ECOG-ACRIN 1512): A randomized, controlled, open-label, multicenter, phase 2 trial. Lancet Oncol. 2016, 17, 1661-1671. [CrossRef]

50. Engstrom, L.D.; Aranda, R.; Lee, M.; Tovar, E.A.; Essenburg, C.J.; Madaj, Z.; Chiang, H.; Briere, D.; Hallin, J.; Lopez-Cass, P.P.; et al. Glesatinib exhibits antitumor activity in lung cancer models and patients harboring MET exon 14 mutations and overcomes mutation-mediated resistance to Type I MET inhibitors in nonclinical models. Clin. Cancer Res. 2017, 23, 6661-6672. [CrossRef] [PubMed]

51. Michieli, P.; Mazzone, M.; Basilico, C.; Cavassa, S.; Sottile, A.; Naldini, L.; Comoglio, P.M. Targeting the tumor and its microenvironment by a dual-function decoy Met receptor. Cancer Cell 2004, 6, 61-73. [CrossRef] [PubMed]

52. Merchant, M.; Ma, X.; Maun, H.R.; Zheng, Z.; Peng, J.; Romero, M.; Huang, A.; Yang, N.Y.; Nishimura, M.; Greve, J.; et al. Monovalent antibody design and mechanism of action of onartuzumab, a MET antagonist with anti-tumor activity as a therapeutic agent. Proc. Natl. Acad. Sci. USA 2013, 110, E2987-E2996. [CrossRef] [PubMed]

53. Salgia, R.; Patel, P.; Bothos, J.; Yu, W.; Eppler, S.; Hegde, P.; Bai, S.; Kaur, S.; Nijem, I.; Catenacci, D.V.; et al. Phase I dose-escalation study of onartuzumab as a single agent and in combination with bevacizumab in patients with advanced solid malignancies. Clin. Cancer Res. 2014, 20, 1666-1675. [CrossRef] [PubMed]

54. Spigel, D.R.; Ervin, T.J.; Ramlau, R.A.; Daniel, D.B.; Goldschmidt, J.H.; Blumenschein, G.R.; Krzakowski, M.J.; Robinet, G.; Godbert, B.; Barlesi, F.; et al. Randomized phase II trial of Onartuzumab in combination with erlotinib in patients with advanced non-small-cell lung cancer. J. Clin. Oncol. 2013, 31, 4105-4114. [CrossRef] [PubMed] 
55. Koeppen, H.; Yu, W.; Zha, J.; Pandita, A.; Penuel, E.; Rangell, L.; Raja, R.; Mohan, S.; Patel, R.; Desai, R.; et al. Biomarker analyses from a placebo-controlled phase II study evaluating Erlotinib \pm Onartuzumab in advanced non-small cell lung cancer: MET expression levels are predictive of patient benefit. Clin. Cancer Res. 2014, 20, 4488-4498. [CrossRef] [PubMed]

56. Brower, V. Onartuzumab ineffective in non-small cell lung cancer. Lancet Oncol. 2016, 18, e66. [CrossRef]

57. Liu, L.; Zeng, W.; Wortinger, M.A.; Yan, S.B.; Cornwell, P.; Peek, V.L.; Stephen, J.R.; Tetreault, J.W.; Xia, J.; Manro, J.R.; et al. LY2875358, a neutralizing and internalizing anti-MET bivalent antibody, inhibits HGF-dependent and HGF-independent MET activation and tumor growth. Clin. Cancer Res. 2014, 20, 6059-6070. [CrossRef] [PubMed]

58. Rosen, L.S.; Goldman, J.W.; Algazi, A.P.; Turner, P.K.; Moser, B.; Hu, T.; Wang, S.A.; Tuttle, J.; Wacheck, V.; Woolridge, J.E.; et al. A first-in-human phase I study of a bivalent MET antibody, Emibetuzumab (LY2875358), as monotherapy and in combination with erlotinib in advanced cancer. Clin. Cancer Res. 2017, 23, 1910-1919. [CrossRef] [PubMed]

59. Patnaik, A.; Gordon, M.; Tsai, F.; Papadopoulous, K.; Rasco, D.; Beeram, S.M.; Fu, S.; Janku, F.; Hynes, S.M.; Gundala, S.R.; et al. A phase 1 study of LY3164530, a bispecific antibody targeting MET and EGFR, in patients with advanced or metastatic cancer. Cancer Chemother. Pharmacol. 2018. [CrossRef]

60. Moores, S.L.; Chiu, M.L.; Bushey, B.S.; Chevalier, K.; Luistro, L.; Dorn, K.; Brezski, R.J.; Haytko, P.; Kelly, T.; Wu, S.J.; et al. A novel bispecific antibody targeting EGFR and cMet is effective against EGFR inhibitor-resistant lung tumors. Cancer Res. 2016, 76, 3942-3953. [CrossRef] [PubMed]

61. Emdal, K.B.; Dittmann, A.; Reddy, R.J.; Lescarbeau, R.S.; Moores, S.L.; Laquerre, S.; White, F.M. Characterization of in vivo resistance to osimertinib and JNJ-61186372, an EGFR/Met bispecific antibody, reveals unique and consensus mechanisms of resistance. Mol. Cancer Ther. 2017, 16, 2572-2585. [CrossRef] [PubMed]

62. Jarantow, S.W.; Bushey, B.S.; Pardinas, J.R.; Boakye, K.; Lacy, E.R.; Sanders, R.; Sepulveda, M.A.; Moores, S.L.; Chiu, M.L. Impact of cell-surface antigen expression on target engagement and function of an epidermal growth factor receptor $\times$ c-MET bispecific antibody. J. Biol. Chem. 2015, 290, 24689-24704. [CrossRef] [PubMed]

63. Lee, B.-S.; Kang, S.; Kim, K.-A.; Song, Y.-J.; Cheong, K.H.; Cha, H.-Y.; Kim, C.H. Met degradation by SAIT301, a Met monoclonal antibody, reduces the invasion and migration of nasopharyngeal cancer cells via inhibition of EGR-1 expression. Cell Death Dis. 2014, 5, e1159. [CrossRef] [PubMed]

64. Wang, J.; Goetsch, L.; Tucker, L.; Zhang, Q.; Gonzalez, A.; Vaidya, K.S.; Oleksijew, A.; Boghaert, E.; Minghao, S.; Sokolova, I.; et al. Anti-c-Met monoclonal antibody ABT-700 breaks oncogene addiction in tumors with MET amplification. BMC Cancer 2016, 16, 1-14. [CrossRef] [PubMed]

65. Burgess, T.L.; Sun, J.; Meyer, S.; Tsuruda, T.S.; Sun, J.; Elliott, G.; Chen, Q.; Haniu, M.; Barron, W.F.; Juan, T.; et al. Biochemical characterization of AMG 102: A neutralizing, fully human monoclonal antibody to human and nonhuman primate hepatocyte growth factor. Mol. Cancer Ther. 2010, 9, 400-409. [CrossRef] [PubMed]

66. Iveson, T.; Donehower, R.C.; Davidenko, I.; Tjulandin, S.; Deptala, A.; Harrison, M.; Nimi, S.; Lakshmaiah, K.; Thomas, A.; Jiang, Y.; et al. Rilotumumab in combination with epirubicin, cisplatin, and capecitabine as first-line treatment for gastric or oesophagogastric junction adenocarcinoma: An open-label, dose de-escalation phase $1 \mathrm{~b}$ study and a double-blind, randomised phase 2 study. Lancet Oncol. 2014, 15, 1007-1018. [CrossRef]

67. Cunningham, D.; Tebbutt, N.C.; Davidenko, I.; Murad, A.M.; Al-Batran, S.-E.; Ilson, D.H.; Tjulandin, S.; Gotovkin, E.; Karaszewska, B.; Abdulaziz, M.; et al. Phase III, randomized, double-blind, multicenter, placebo $(\mathrm{P})$-controlled trial of rilotumumab (R) plus epirubicin, cisplatin and capecitabine (ECX) as first-line therapy in patients (pts) with advanced MET-positive (pos) gastric or gastroesophageal junction (G/GEJ) cancer: RILOMET-1 study. J. Clin. Oncol. 2015, 33. [CrossRef]

68. Tarhini, A.A.; Rafique, I.; Floros, T.; Tran, P.; Gooding, W.E.; Villaruz, L.C.; Burns, T.E.; Friedland, D.M.; Pertro, D.P.; Farooqui, M.; et al. Phase 1/2 study of rilotumumab (AMG 102), a hepatocyte growth factor inhibitor, and erlotinib in patients with advanced non-small cell lung cancer. Cancer 2017, 123, $2936-2944$. [CrossRef] [PubMed]

69. Patnaik, A.; Weiss, G.J.; Papadopoulos, K.P.; Hofmeister, C.C.; Tibes, R.; Tolcher, A.; Issacs, R.; Jac, J.; Han, M.; Payumo, F.C.; et al. Phase I ficlatuzumab monotherapy or with erlotinib for refractory advanced solid tumours and multiple myeloma. Br. J. Cancer 2014, 111, 272-280. [CrossRef] [PubMed] 
70. Elez, M.E.; Herranz, M.; Rico, I.; Prudkin, L.; Andreu, J.; Mateos, J.; Carreras, M.; Han, M.; Gifford, J.; Credi, M.; et al. A pharmacodynamic/pharmacokinetic study of ficlatuzumab in patients with advanced solid tumors who have liver metastases. Clin. Cancer Res. 2014, 20, 2793-2804.

71. Mok, T.S.K.; Geater, S.L.; Su, W.C.; Tan, E.H.; Yang, J.C.; Chang, G.C.; Han, M.; Komarnitsky, P.; Payumo, F.; Garrus, J.E.; et al. A randomized phase 2 study comparing the combination of ficlatuzumab and gefitinib with gefitinib alone in Asian patients with stage pulmonaryadenocarcinoma. J. Thorac. Oncol. 2016, 11, 1736-1744. [CrossRef] [PubMed]

72. Okamoto, W.; Okamoto, I.; Tanaka, K.; Hatashita, E.; Yamada, Y.; Kuwata, K.; Yamaguchi, H.; Arao, T.; Nishio, K.; Fukoka, M.; et al. TAK-701, a humanized monoclonal antibody to hepatocyte growth factor, reverses gefitinib resistance induced by tumor-derived HGF in non-small cell lung cancer with an EGFR mutation. Mol. Cancer Ther. 2010, 9, 2785-2792. [CrossRef] [PubMed]

73. Kim, K.; Hur, Y.; Ryu, E.-K.; Rhim, J.-H.; Choi, C.Y.; Baek, C.-M.; Lee, J.H.; Chung, J. A neutralizable epitope is induced on HGF upon its interaction with its receptor cMet. Biochem. Biophys. Res. Commun. 2007, 354, 115-121. [CrossRef] [PubMed]

74. Woo, J.K.; Kang, J.-H.; Kim, B.; Park, B.H.; Shin, K.-J.; Song, S.-W.; Kim, J.J.; Kim, H.M.; Lee, S.J.; Oh, S.H. Humanized anti-hepatocyte growth factor (HGF) antibody suppresses innate irinotecan (CPT-11) resistance induced by fibroblast-derived HGF. Oncotarget 2015, 6, 24047-24060. [CrossRef] [PubMed]

75. Fiedler, U.; Ekawardhani, S.; Cornelius, A.; Gilboy, P.; Bakker, T.R.; Dolado, I.; Stumpp, M.T.; Dawson, K.M. MP0250, a VEGF and HGF neutralizing DARPin ${ }^{\circledR}$ molecule shows high anti-tumor efficacy in mouse xenograft and patient-derived tumor models. Oncotarget 2017, 8, 98371-98383. [CrossRef] [PubMed]

76. Petrelli, A.; Circosta, P.; Granziero, L.; Mazzone, M.; Pisacane, A.; Fenoglio, S.; Comoglio, P.M.; Giordana, S.; et al. Ab-induced ectodomain shedding mediates hepatocyte growth factor receptor down-regulation and hampers biological activity. Proc. Natl. Acad. Sci. USA 2006, 103, 5090-5095. [CrossRef] [PubMed]

77. Pacchiana, G.; Chiriaco, C.; Stella, M.C.; Petronzelli, F.; De Santis, R.; Galluzzo, M.; Carminati, P.; Comoglio, P.M.; Michieli, P.; Vigna, E. Monovalency unleashes the full therapeutic potential of the DN-30 anti-Met antibody. J. Biol. Chem. 2010, 285, 36149-36157. [CrossRef] [PubMed]

78. Vigna, E.; Pacchiana, G.; Chiriaco, C.; Cignetto, S.; Fontani, L.; Michieli, P.; Comoglio, P.M. Targeted therapy by gene transfer of a monovalent antibody fragment against the Met oncogenic receptor. J. Mol. Med. 2014, 92, 65-76. [CrossRef] [PubMed]

79. Cignetto, S.; Modica, C.; Chiriaco, C.; Fontani, L.; Milla, P.; Michieli, P.; Comoglio, P.M.; Vigna, E. Dual constant domain-Fab: A novel strategy to improve half-life and potency of a Met therapeutic antibody. Mol. Oncol. 2016, 10, 938-948. [CrossRef] [PubMed]

80. Gimenez-Xavier, P.; Pros, E.; Bonastre, E.; Moran, S.; Aza, A.; Grana, O.; Gomez-Lopez, G.; Derdak, S.; Dabad, M.; Esteve-Codina, A. Genomic and molecular screenings identify different mechanisms for acquired resistance to MET inhibitors in lung cancer cells. Mol. Cancer Ther. 2017, 16, 1366-1376. [CrossRef] [PubMed]

81. Qi, J.; McTigue, M.A.; Rogers, A.; Lifshits, E.; Christensen, J.G.; Janne, P.A.; Engelman, J.A. Multiple mutations and bypass mechanisms can contribute to development of acquired resistance to MET inhibitors. Cancer Res. 2011, 71, 1081-1091. [CrossRef] [PubMed]

82. Botting, G.M.; Rastogi, I.; Chhabra, G.; Niend, M.; Puri, N. Mechanism of resistance and novel targets mediating resistance to EGFR and c-Met tyrosine kinase inhibitors in non-small cell lung cancer. PLoS ONE 2015, 10, e0136155. [CrossRef] [PubMed]

83. Pennacchietti, S.; Cazzanti, M.; Bertotti, A.; Rideout, W.M.; Han, M.; Gyuris, J.; Perara, T.; Comoglio, P.M.; Trusolino, L.; Michieli, P. Microenvironment-derived HGF overcomes genetically determined sensitivity to anti-MET drugs. Cancer Res. 2014, 74, 6598-6609. [CrossRef] [PubMed]

84. Straussman, R.; Morikawa, T.; Shee, K.; Barzily-Rokni, M.; Qian, Z.R.; Du, J.; Davis, A.; Mogare, M.M.; Gould, J.; Fredrick, D.T.; et al. Tumour micro-environment elicits innate resistance to RAF inhibitors through HGF secretion. Nature 2012, 487, 500-504. [CrossRef] [PubMed]

85. Kobayashi, S.; Boggon, T.J.; Dayaram, T.; Janne, P.A.; Kocher, O.; Meyerson, M.; Johnson, B.E.; Eck, M.J.; Tenen, D.G.; Halmos, B. EGFR mutation and resistance of non-small-cell lung cancer to gefitinib. N. Engl. J. Med. 2005, 352, 786-792. [CrossRef] [PubMed]

86. Engelman, J.A.; Zejnullahu, K.; Mitsudomi, T.; Song, Y.; Hyland, C.; Park, J.O.; Lindeman, N.; Gale, C.M.; Zhao, X.; Christensen, J.; et al. MET amplification leads to gefitinib resistance in lung cancer by activating ERBB3 signaling. Science 2007, 316, 1039-1043. [CrossRef] [PubMed] 
87. Yano, S.; Wang, W.; Li, Q.; Matsumoto, K.; Sakurama, H.; Nakamura, T.; Ogino, H.; Kakiuchi, S.; Hanibuchi, M.; Nishioka, Y.; et al. Hepatocyte growth factor induces gefitinib resistance of lung adenocarcinoma with epidermal growth factor receptor activating mutations. Cancer Res. 2008, 68, 9479-9487. [CrossRef] [PubMed]

88. Sakamoto, H.; Tsukaguchi, T.; Hiroshima, S.; Kodama, T.; Kobayashi, T.; Fukami, T.A.; Oikawa, N.; Tsukada, T.; Ishii, N.; Aoki, Y. CH5424802, a selective ALK inhibitor capable of blocking the resistant gatekeeper mutant. Cancer Cell 2011, 19, 679-690. [CrossRef] [PubMed]

89. Isozaki, H.; Ichihara, E.; Takigawa, N.; Ohashi, K.; Ochi, N.; Yasugi, M.; Nonomiya, T.; Yamane, H.; Sakai, K.; Matsumota, K.; et al. Non-small cell lung cancer cells acquire resistance to the ALK inhibitor alectinib by activating alternative receptor tyrosine kinases. Cancer Res. 2016, 76, 1506-1516. [CrossRef] [PubMed]

(C) 2018 by the authors. Licensee MDPI, Basel, Switzerland. This article is an open access article distributed under the terms and conditions of the Creative Commons Attribution (CC BY) license (http:/ / creativecommons.org/licenses/by/4.0/). 